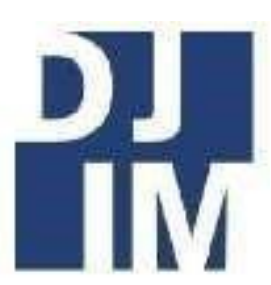

\title{
Volume 16
}

Spring

2021

ojs.library.dal.ca/djim

\section{"Moral Bonfires": An Exploration of Book Burning in American Society}

Lisa Olson

School of Information Management, Faculty of Management, Dalhousie University

\section{Abstract}

This article seeks to offer an introduction to book burning in American society. Firstly, it considers the use of fire as a method of destruction and its relation to freedom of speech and the American judicial system. It then seeks to unearth the reasons for book burning through an examination of a number of instances throughout American history. The phenomenon of book burning has been occurring worldwide for thousands of years, and as a longstanding tradition that has always drawn visceral reactions from spectators, it is still happening with alarming frequency. In America, book burning walks the fine line between censorship and free speech. It remains, however, an attack on knowledge and culture and is consequently a threat to the information management field. This paper, therefore, seeks to explore these occurrences from recent American history and discover why Americans have been, and are still burning books, in an attempt to better understand these attacks. 
Key Words: America, Book Burning, Censorship, Freedom of Speech, United States

\section{Introduction}

Western culture is imbued with information; as Webster (2014) writes, "there is simply a great deal more of it than ever before" (p. 21). In an information society such as this, the deliberate destruction of books is a particularly distressing concept to many, though it has been happening far and wide for centuries. This concerns information management because, as Ovenden (2020) notes, "there can be no access without preservation" (p. 8). Access to information is crucial for a democratic society and preservation of information is one of the main goals of librarians, archivists, and other information management professionals working in cultural institutions. As Knuth (2006) notes, the destruction of books is the destruction of culture. This is true whether it is an organized attack on an entire country's libraries or one person burning one book. Book burning, therefore, is not just an attack on books: it is an attack on culture and those who seek to protect it through the preservation of knowledge.

There are myriad situations that can lead to book burning, the only constant being that someone is always left in a state of formidable awe, awe at the act of destruction, the target of the destruction, or how the destruction was achieved. Book burning can be the result of totalitarian regimes, as was the case in Nazi 2
Germany, the Soviet Union, and the Qin Dynasty (Brand, 1999). It can also be the result of war, as was the case with the American Library of Congress in 1814 and the National and University Library of Bosnia and Herzegovina in 1992 (Ovenden, 2020). Likewise, it can be the result of religious strife as in the 1782 burning of a rabbi's book by a German Jewish community (Aronsfeld, 1982); politics, as was the case with many book burnings in Tudor England (Cressy, 2005); or rebellion, as was the case with protesters burning Gaddafi's Green Book during the First Libyan Civil War (The Guardian, 2011). It can be a tool of censorship, an act intended to induce fear, a statement of power, or even just a means of personal satisfaction. Regardless of the reason, history is littered with a relentless succession of book burnings all over the world, including in the United States.

For what reasons did and do Americans burn books? Book burning in the United States is an ineffective form of censorship as it tends to lead to an increase in sales and "near immortality" for the book in question, which is then automatically inducted into the American Library Association's “coveted list of 'challenged and banned books,' ensuring that it will be stocked and read well into the next century" (Lott, 2002, p. 76). That said, censorship is rarely the purpose of book burning. Marking (2002) notes:

"Moral Bonfires" 
The point of burning a book is visibility: the public display of a book in its death throes. Burning a book is qualitatively different from merely suppressing it. Where censorship is a means of social control, an attempt to impose order, book burning is essentially disorderly. It is populist and often out of control. It requires passion. Those who fling books onto flames often talk about purging, purification, exorcising, punishment, revenge. (p. 63)

From novels to religious texts to comic books, the United States has a long history of burning books and the purpose is more often than not to make a statement; it is rarely intended to censor. This paper will first explore why fire is the most iconic means for the destruction of books and the legality of book burning in the United States. It will then explore the reasons behind American book burnings through an examination of case studies.

\section{Fire as a Method of Destruction}

Books can be and have been destroyed in a multitude of ways throughout history. Though book burnings were common in Nazi Germany, there was at least one instance where children "rode bicycles over pages of the Torah, shredded them, [and] played with them" (Confino, 2012, pp. 370-371). In the United States, a church that was refused a permit for a bonfire to burn the Harry Potter books instead held a "book cutting" ceremony, but it was noted that this ended up being a "somewhat comical exercise lacking both the symbolism and the power of burning" (Marking, 2002, pp. 66-67). So why is fire the preferred method of book destruction?

In 1753 the Council of Polish Jews decided that when it came to literature, "the best form of destruction is incineration" (Bosmajian, 2006, p. 132). It is not all about practicality, however. Fire can be interpreted as a symbol of Hell, purification, anger, and many more abstract concepts. Joseph Goebbels, Nazi Germany's Minister of Propaganda, gave a speech in Berlin during the burning of 20,000 books in which he said, "This is a powerful, huge and symbolic action that will tell the entire world that the old spirit is dead. From the ashes will rise the phoenix of the new spirit" (Marking, 2002, p. 63). Manley (2002) provides further explanation for the use of fire in the destruction of books:

If you want to make a strong statement about something, it's hard to find a stronger image to use than fire. When God revealed himself to Moses, he did so as a burning bush. When Jesus attempted to describe the pain of hell, he conjured up a terrifying portrait of eternal flames. When the white-hooded thugs of the $\mathrm{Ku}$ Klux Klan rode 
menacingly through the rural South to stir up the hatred of racism, they burned crosses on people's front yards. When anti-war dissidents protested U.S. involvement in the Vietnam War, they burned the American flag. When Buddhist monks protested the corrupt Diem regime in South Vietnam, they burned themselves. When the Nazis wanted to rid Germany of dangerous and undesirable ideas, they burned piles and piles of books. (p. 196)

Fire does not just annihilate its victims, it makes a statement; one that the burners are conveying to the authors of the works being burned, and the witnesses of the burning. Bradbury's book Fahrenheit 451 begins with the lines "It was a pleasure to burn. It was a special pleasure to see things eaten, to see things blackened and changed" (Bradbury, 2008, p. 9). This is a feeling that some book burners are undoubtedly familiar with, though few other forms of destruction could result in the same outcome. History and literature have shown us that fire is an anarchic, uncontrollable, and chaotic form of destruction to which other methods of destruction cannot compare.

\section{Book Burning and the Law}

On December $15^{\text {th }}, 1791$, the Bill of Rights was ratified, bringing the First Amendment to American citizens. The First Amendment states that "Congress shall make no law respecting an establishment of religion, or prohibiting the free exercise thereof; or abridging the freedom of speech, or of the press; or the right of the people peaceably to assemble, and to petition the Government for a redress of grievances" (The U.S. National Archives and Records Administration, n.d., The U.S. Bill of Rights section). American citizens tend to be very passionate about maintaining freedom of speech; many consider it a "sacrosanct principle of American culture," and yet, the application of the First Amendment is still disputed (Blue Holmes, 2012, p. 462). While the concept of free speech is generally one that people agree to be vital, many Americans wonder if certain actions that can be considered freedom of speech should be illegal, such as hate speech, and the burning of flags and books. It is within this moral and legal grey area that book burning thrives.

While government-orchestrated book burnings are still common in some countries, they are fairly uncommon in the United States. The U.S. Post Office, however, has a long history of censorship, and that includes burning books. Throughout the 1920s, for example, all copies of James Joyce's Ulysses arriving in the United States through the post office were burned in what the book's editor and publisher compared to "a burning at the stake" (Marking, 2016, p. 67). She mournfully professed, "the tears, prayers, hysterics and rages we used on printer, binder, paper houses; the 
addressing, wrapping, stamping, mailing; the excitement of anticipating the world's response to the literary masterpiece of our generation," only to receive a notice from the post office that it had been burned (Marking, 2016, p. 67).

In another scenario, Anonymous (1993) tells the story of a man named Ferris Alexander, who owned a number of retail stores throughout Minnesota which sold pornographic materials. They write that in 1989, Alexander was convicted of various counts of obscenity and racketeering resulting in the forfeiture of all of his materials and businesses. These materials were then destroyed, presumably through burning (Anonymous, 1993). While some felt that this violated the First Amendment, one person stating that it was not borne of "the power to punish an individual for his past transgressions but the authority to supress a particular class of disfavored speech," in 1993 the Supreme Court decided that this was not the case (Anonymous, 1993, p. 6). This resulted in the publishing of an opinion piece in Editor \& Publish stating "We despise pornography and those who deal in it. But we despise book burning even more" (Anonymous, 1993, p. 6). They also posited that "independence of speech and press can be just as compromised by the threat of official intervention as by the fact of it," claiming that the Supreme Court's decision set an awful precedent (Anonymous, 1993, p.6). It was not the last time that it would happen.

"Moral Bonfires"
On September $11^{\text {th }}, 2010$, a New Jersey Transit employee named Derek Fenton attended a protest against The Ground Zero Mosque on his day off, and burned pages of the Quran (Sclafane, 2011). He was wearing nothing related to his work, but he was terminated when the video of him burning the Quran went viral. While New Jersey Transit claimed that he violated their code of conduct, the American Civil Liberties Union (ACLU) brought a suit on his behalf arguing that his termination violated the First Amendment, and Fenton was reinstated the following year, reimbursed for lost wages, and awarded \$25,000 in compensation in exchange for him dropping his lawsuit (Vitello, 2011). Deborah Jacobs, executive director of the New Jersey ACLU said, "in America, we have the right to burn all kinds of things letters, flags, books, Bibles and Korans," noting that this case ought to "serve as a reminder to our leaders that they can't punish and censor political expression based on their own emotional reactions or sense of morality" (Vitello, 2011, paras. 3-4). With this in mind, book burners often use the First Amendment as a defence for what they are doing. One reverend noted at a religious bonfire that "there's no such thing as a crusade to deal with other people's things,"' because "'that's their business," going on to state that they believe in the First and Second Amendments as well as the First and Second Commandments (ABC News, 2002, para. 6). 
The Supreme Court supported the burning of pornographic materials in 1993, and the ACLU as well as a County Prosecutor from Michigan supported the burning of the Quran in 2011 (Anonymous, 1993; Blue Holmes, 2012; Vitello, 2011). Furthermore, Blue Holmes (2012) evaluates the Constitution as well as precedent and resolves that if a book burning can be considered symbolic speech rather than mere conduct, if it does not encourage unlawful action or cause harm, and if it is not likely to incite immediate violence or retaliation from spectators, then it is likely considered to be legal by American courts. While there is still debate about the legality of book burning in the United States, there are no federal laws that make it illegal.

\section{Book Burning and American Society}

Book burning in America is quite different from book burning in other countries. Blue Holmes (2012) notes that while Quran burning is generally regarded as legal in the United States, this would likely not be the case in European courts due to laws surrounding national security which aim to limit violence against other cultures. Following the realization that antisemitic propaganda was connected to the rise of Nazism in Germany, many European countries in particular crafted laws that "restrict speech and conduct based on the content of the message," (Blue Holmes, 2012, p. 467). In the years following
$9 / 11$, some countries created further statutes, for example, the prohibition of "incitement to religious hatred" in France and the Racial \& Religious Hatred Act in England which have both led to criminal charges for Quran burnings (Blue Holmes, 2012, p. 467).

While Blue Holmes (2012) believes that it is risky to allow free speech to the extent that America does, she notes that it is not nearly as risky as the European model of allowing each state to decide what is or is not acceptable speech. While the evidence shows that book burning is not illegal in the United States, the morality of it is questioned even more than its legality. This is why there are often more protesters than book burners at these events (Marking, 2002). This is where the opposition thrives.

Book burning in America is not about censorship: it is about the opposite, free speech and making a statement that is rooted in a deep sense of morality. Marking (2002) notes that American book burnings are "mainly inspired by the morality of the religious right," referring to them as "moral bonfires" (p. 67). These book burnings are statements that express one's ideals and opinions; they can be religious, racist, homophobic, or political. This paper will explore a number of motivations used by book burners in America, namely personal ideals, disagreement with religious texts (often combined with racism), disapproval of secular texts by religious officials, and concern for the children of America.

"Moral Bonfires" 
Personal Ideals

Some book burners are simply average American citizens who burn books that oppose their views. Marking (2002) tells of a few of these instances. Kathleen Winsor's historical romance novel Forever Amber, for example, sold 100,000 copies the week following its publication in 1944, but it was quickly banned in many states and burned in the streets of Boston due to its sexual nature. She also mentions that in the 1950s, the Food and Drug Administration burned six tons of William Reich's work on sexual matters. Finally, Irving Wallace's The Man, a book published in 1964 that speculated the possibility of a black man becoming President of the United States, was burned in Michigan (Marking, 2002). The majority of books burned in this category are liberal in nature, often exploring racism or sexuality.

In June of 2019, one such book burning occurred due to homophobia. As American libraries were preparing for Pride month, the American Library Association released their State of America's Libraries 2019 Report showing a growing bias towards the LGBTQIA+ community and an increase in organized groups engaging in extreme tactics; one such group appeared in lowa, burning books that contained LGBTQIA+ content (Yorio, 2019). That same year a book burning was borne out of racist ignorance. Jennine Capo Crucet is an associate professor of English at the University of Nebraska (Fisher, 2019). Her 2015 novel Make Your Home Among Strangers tells of the "Moral Bonfires" experiences of a Latina woman at a majority white college and when Crucet was invited to speak at Georgia Southern University, to a firstyear class that had read her book as part of the course's required reading, the concept of white privilege was bound to come up (Fisher, 2019).

When it did, many students became argumentative and accused Crucet of being racist (Fisher, 2019). After the event, some of the students gathered around a grill and burned a copy of her book in what PEN America (2019) described as "a disturbing practice that emblemizes hostility toward free expression" (para. 1). Fisher (2019) notes that it was filmed and posted on the internet, and some reports stated that students showed up at Cruset's hotel, yet no students were penalized. Crucet was supposed to speak at a second Georgia Southern University campus but it was cancelled due to the university's inability to protect her, owing to Georgia's open-carry gun law (Fisher, 2019).

Book burning in these cases involves citizens using fire to make a statement about their views and contesting material that did not suit their conservative ideals. It is not always conservative ideals that are the problem, however. When Canadian author Lawrence Hill published his award-winning The Book of Negroes in the United States, he was told that he would have to change the title because no bookstores would place advanced orders for a book with the word 'negro' in the title (Hill, 2013). As was the case with many 
other authors including as J.K. Rowling and Alice Munro, Hill's book title was "altered to suit the whims of American publishers" (Hill, 2013, p. 7). This type of censorship may have actually prevented the book's burning in the United States. Published under its original title in the Netherlands, less than a month after being released, The Book of Negroes was burned specifically because of the title, because they believed that Hill was bringing the racist term 'negro' back into the public sphere (Hill, 2013). It was not burned in the United States, however, under the title of Someone Knows My Name (Hill, 2013). Nonetheless, Hill (2013) was told by some American citizens that they never would have read his book if it had been published under its original title; perhaps they would have even burnt it. Instances of book burning because of liberal or anti-racist ideals, however, are not common in the United States.

\section{Disagreement with Religious Texts}

Americans also burn religious texts, which is often attributed to their own religious ideals. In these scenarios, the motivations for the book burning often stem partially from racism. Most instances of burning religious texts in the United States occur with the Quran, illuminating the prevalence of Islamophobia in America, though there are instances of burning The Book of Mormon as well (Marking, 2002). On September $11^{\text {th }}, 2010$, the ninth anniversary of the events of $9 / 11$, pastor Terry Jones from Florida had intended to commemorate the occasion with a Quran bonfire (Anonymous, 2010). The news of this event spread worldwide and there were protests in Afghanistan, Iran, Somalia, and other countries, some of which resulted in the burning of American flags (Blue Holmes, 2012; Healy \& Erlanger, 2010). President Obama told Jones that going through with the event would put American soldiers in danger, and Christian churches in Baghdad hired armed guards to protect them in case they were attacked (Healy \& Erlanger, 2010). The event was cancelled after Jones received public criticism from a number of people worldwide, including then General David Patraceus, Defense Secretary Robert Gates, Secretary of State Hillary Clinton, and President Barrack Obama (Anonymous, 2010; Blue Holmes, 2012). There was nothing to stop him from burning Qurans in 2011 and 2012. In 2013, Jones was pulled over for a traffic violation and was subsequently arrested for the dangerous transportation of fuel: he had nearly 3000 kerosene-soaked Qurans in the bed of his pickup truck (Peralta, 2013).

Furthermore, while Jones eventually cancelled his 2010 bonfire, it was widely publicized along with the video of Derek Fenton burning pages of the Quran at a protest in New York (Sclafane, 2011). Following these two instances, Quran burnings arose in England, France, and Michigan (Blue Holmes, 2012). Clearly the burning of religious texts can have significant global consequences, 
and there is more to worry about than just the morality of book burning.

\section{Disapproval of Secular Texts by Religious Officials}

Finkelstein and McCleery (2005) note that while most Western European and North American states have stopped censoring books for moral reasons, "the cudgel has been taken up by lobby groups such as religious fundamentalists" who seek to ban books (p. 132). They also burn books, however. The instances of religious officials burning secular texts generally occur when said officials deem a work of literature to be promoting non-Christian values, to be the work of Satan, or to be an affront to God. This can result in a frenzy of religious fundamentalists rounding up and destroying pop culture items that they believe to be a threat to their faith. These religious groups burn books "in protest against offensive values" which they claim have been pushing their "Christian faith and influence to the margins of American life" (Knuth, 2006, p. x). Sometimes it becomes a regular event, with Marking (2002) noting that book burnings have become "a Sunday evening ritual for many congregations" (p. 66).

In one instance on March 26 $6^{\text {th }}, 2001$, a church in Pittsburgh, Pennsylvania held a bonfire for members of the congregation to burn any materials that they deemed not in keeping with their faith (ABC News, 2006; Marking, 2002).
Materials that were burned included the Harry Potter books, The Book of Mormon, the Disney films Pinocchio and Hercules, and the CDs of Pearl Jam and Black Sabbath (ABC News, 2006; Marking, 2002). Reverend George Bender assured reporters that it was an optional ceremony, noting that only one third of congregants brought material to burn (ABC News, 2006). Bender also claimed that they were really following the Bible, in which people received Jesus Christ as their savior and followed up by burning items from their homes; members of his congregation were doing the same ( $A B C$ News, 2006).

Around 2001 a trend emerges concerning religious book burnings in the United States and JK Rowling's Harry Potter books are the common denominator. Knuth (2006) notes that pastors claimed that these book burnings aimed at the Harry Potter books were "a means for Christians to build community, affirm their allegiance to God, and separate themselves from a pop culture they believed to be detrimental to society" (p. x). At the aforementioned bonfire, Bender noted that Harry Potter was "the big flashpoint" and that it is "really bad" as it promotes "sorcery, witchcraft-type things, [and] the paranormal" which are against God (ABC News, 2006, para. 10). He is but one of many religious officials to condemn the Harry Potter books and in studying some of these Harry Potter book burnings, Knuth (2006) notes a "pattern of extremism, 
renunciation, and affirmation" (p. x). Furthermore, Marking (2002) writes that book burning is "redolent of witch burning [and] involves something superstitious and magical," noting that it is therefore unsurprising that the Harry Potter books were the most burned books of the $20^{\text {th }}$ century (p. 63).

On December $30^{\text {th }}, 2001$, the Christ Community Church in Alamogordo, New Mexico held a gathering of about 500 people to usher in the new year (Ishizuka, 2002). The celebration, however, involved a "holy bonfire" lit with the pages of Harry Potter (Lott, 2002, p. 76). Pastor Brock claimed that the books were "an abomination to God" and were liable to "destroy the lives of many young people" while his Christmas Eve sermon had people choosing between Jesus Christ and Harry Potter (Lott, 2002, p. 76). They also burned the Lord of the

Rings, the Complete Works of William Shakespeare, and various personal items volunteered by the congregation, one girl ridding herself of a Backstreet Boys tape with the intention of strengthening her bond with Jesus Christ (Ishizuka, 2002). While some fundamentalists were in support of the spectacle, most of the town was mortified and the event drew over 800 protesters, including an Adolf Hitler impersonator (Lott, 2002). The event was widely reported and resulted in an influx of opinion pieces in the news comparing pastor Brock to Nazis and the Taliban (Lott, 2002). It also caused the public library to promote the Harry Potter books and instigated a number of cash donations which were then used to buy more copies of the books that had been burned (Ishizuka, 2002). These religious book burnings can have a significant impact on members of the church's congregation, though they receive much criticism from outsiders.

\section{Concern for American Children}

Finally, books are also burned with the welfare of children in mind. As we have seen with the Harry Potter books, some children's literature can cause concern or criticism of a religious or moral nature causing parents or religious officials to burn the books. Manley (2002) points out the futility of these reactions, however, writing:

So how do you deal with a wizard who is mesmerizing your children? If you're really clueless about the magical arts, you will do something stupid like trying to burn him in hopes that he will instantly vanish. Anyone who knows anything about wizards or sorcerers, however, recognizes that this approach is probably the worst thing that you can do. Wizards have a way of miraculously reappearing stronger than ever, and in Harry's case that is exactly what is happening. (p. 196) Manley (2002) posits that the people burning Harry Potter are not only clueless about wizards but are also clueless about children, who tend to 
be drawn towards the items that their parents have banned or burned. He jokingly wonders if perhaps the "book burnings are really a ruse to get kids back into libraries" where they can find more copies of the books that have been burned (Manley, 2002, p. 196).

The burning of children's books was not a phenomenon that emerged with the publishing of Harry Potter, however, and children have not always opposed the burnings. When someone in authority decides that a piece of literature is affecting child development, it can result in a frenzy of parental concern and this is what happened across the United States in the 1950s. Boston (2008) notes that "the last great wave of book burnings occurred during the 'Red Scare'" and due to the widespread fear of communism, the American Legion prodded children into gathering and burning books that promoted juvenile delinquency (p. 37). The Comics Magazine Association of America (CMAA) also responded to this societal phenomenon in 1954 by creating the Comic Code Authority (CCA) to regulate the content of comic books (CMAA, 1954). Restrictions for comic books submitted for the stamp of approval were varied, such as "no unique or unusual methods of concealing weapons shall be shown, except where such concealment could not reasonably be duplicated;" that titles could not include the words "horror" or "terror," and that the word "crime" could not be larger than the rest of the words in the title; that nudity is prohibited and "females shall be drawn realistically without undue emphasis on any physical qualities;" that "divorce shall not be treated humorously;" and that "sexual abnormalities are unacceptable" (CMAA, 1954, pp. 2-5). In response to this, schools and anywhere else that children assembled, felt tasked to rid their communities of comic books that failed to meet the CCA.

On February $22^{\text {nd }}, 1955$, the St. James Catholic School in Decatur, Illinois, held a public comic book burning on the school grounds (Hajdu, 2008). Kids waved signs reading "Burn the Bad, Read the Good" as they threw comics on to the pyre (Hajdu, 2008, p. 303). That same year, in Indiana, Pennsylvania, a Girl Scout troop launched a campaign called 'Operation CleanUp' which involved going house to house collecting comics that did not meet the CCA seal of approval in an attempt to "rid the homes of Indiana of 'improper' comic books" (Hajdu, 2008, p. 303). These comics were later burned at a ceremony that the Girl Scouts called "a Bonfire of the Future" (Hajdu, 2008, p. 303).

These events were supported by many mothers who were worried about "the dreadful increase of sex crimes and depravity" and believed the comic books to be "cheap and filthy," as well as "lurid, highly colored ... highly seasoned," and poisonous, in one woman's words (Genovar, 1953, paras. 2, 7, 8). Not all children agreed, however. One fourteen-year-old boy from 
Pennsylvania went so far as to write the Senate Subcommittee on Juvenile Delinquency to explain that even though he had been reading comic books for "seven to nine years" he had never robbed a bank and did not think that crime comic books would turn anyone into criminals because they always reinforced the saying that "crime don't pay" (Merdian, 1954, lines 2, 8). Book burnings in schools and organized children's groups are unlikely to happen today, but parents are still liable to destroy materials that they believe to be bad for their children, and similar burnings are likely to continue.

\section{Conclusion}

Americans have burned books for a number of reasons, but the overwhelming theme is that they burn books to make a statement, whether it be political, religious, or moral. Regardless of the motives and the text, however, book burning endorses the destruction of knowledge to the detriment of society. The destruction of knowledge, after all, is enmeshed with the destruction of culture. Moreover, American book burnings are anomalous due to the pervasiveness of the American infatuation with free speech. Freedom of speech can be used to defend or condemn the act of book burning which consequently straddles the line between censorship and freedom of expression. This subsequently puts information management professionals in the position of trying to advocate for the preservation of knowledge by opposing book burnings while still supporting free speech.

However, information management professionals are also in a unique position to respond to book burnings. They can help make books available online where they cannot be burned, and they can promote open access and ensure that libraries have multiple copies of the burned books in order to counteract censorship. Furthermore, they can continue to preserve knowledge and make it accessible to the public in addition to educating the public in a way that could even prevent future book burnings. The American government can also help. Instances of Quran burnings have shown that book burning can have global consequences and have illuminated a shortcoming in the American legal system that other countries have assuaged with national security laws. While book burning is not as pervasive in America as in some other countries, it remains a detriment to society and efforts should be made to counteract it.

\section{References}

ABC News. (2006). Potter tossed in fire at Pa. Church. https://abcnews.go.com/US/story?id=9 3727\&page $=1$

Anonymous. (1993). Book burning. Editor \& Publisher, 126(36), 6.

Anonymous. (2010). Bonfires and vanities. National Review, 62(18), 12-12. 
Aronsfeld, C.C. (1982). Book burning in Jewish history. Index on Censorship, 11(1), 18-

19.

https://doi.org/10.1080/030642282085 33331

Blue Holmes, C. (2012). Quran burning and religious hatred: A comparison of American, international, and European approaches to freedom of speech. Washington University Global Studies Law Review, 11(2), 459-482.

Bosmajian, H. A. (2006). Burning books. McFarland \& Company.

Boston, R. (2008). Fanning the flames: The "Golden Age" of American book burning. The Humanist, 68(4), 36-37.

Bradbury, R. (2008). Fahrenheit 451. Harper Voyager.

Brand, S. (1999). Burning libraries. Whole Earth, 99, 56.

Confino, A. (2012). Why did the Nazis burn the Hebrew Bible? Nazi Germany, representations of the past, and the Holocaust. The Journal of Modern History, 84(2), 369-400.

Comics Magazine Association of America (CMAA). (1954). Code of the Comics Magazine Association of America Inc. https://www.visitthecapitol.gov/exhibiti ons/artifact/code- comicsmagazineassociation-america-inc1954

Cressy, D. (2005). Book burning in Tudor and Stuart England. The Sixteenth Century Journal, 36(2), 359-374.

Finkelstein, D., \& McCleery, A. (2005). An introduction to book history ( $2^{\text {nd }}$ ed.). Routledge.

Fisher, L. (2019, October 11). 'This is where we are, America': After a Latina author talks about race at Georgia Southern U., students burn her book. The Chronicle of Higher Education.

Gaddafi speech, book-burning and conflict in Brega - in pictures. (2011, March 2).

The Guardian. https://www.theguardian.com/world/g allery/2011/mar/02/libyagaddafispeech-book-burning

Genovar, E. Y. (1953, November 24). Letter from Eugenia Y. Genovar regarding comic books censorship, November 24, 1953. Records of U.S. Senate, National Archives and Records Administration. https://www.visitthecapitol.gov/exhibiti ons/artifact/letter-eugeniaygenovarregarding-comicbookcensorshipnovember-24-1953

Hajdu, D. (2008). The ten-cent plague: The great comic-book scare and how it changed America. Farrar, Straus and Giroux. Healy, J., \& Erlanger, S. (2010, September 9). 
Planned Koran burning drew

international scorn. The New York Times. https://www.nytimes.com/2010/09/10/ world/10react.html

Hill, L. (2013). Dear Sir, I intend to burn your book: An anatomy of a book burning. The University of Alberta Press.

Ishizuka, K. (2002). Harry Potter book burning draws fire. School Library Journal, 48(2), 27.

Knuth, R. (2006). Burning books and leveling libraries: Extremist violence and cultural destruction. Praeger Publishers.

Lott, J. (2002, March). Burning sensations. Reason, 33(10), 76-77.

Manley, W. (2002). In defense of book burning. American Libraries, 33(3), 196.

Marking, S. (2002). The house of burned books. Index on Censorship, 31(4), 63-68. https://doi.org/10.1080/030642202085 37138

Merdian, R. (1953, June 22). Letter from Robert Merdian regarding comic book censorship. Records of U.S. Senate, National Archives and Records

Administration

https://www.visitthecapitol.gov/exhibiti ons/artifact/letter-

robertmerdianregarding-comicbookcensorship-june- 22-1954
Murphy, M. J. (2016, June 16). The rough read that was 'Ulysses.' The New York Times. https://www.nytimes.com/2016/06/17/ books/the-rough-readthatwasulysses.html

Ovenden, R. (2020). Burning the books: A history of the deliberate destruction of knowledge. The Belknap Press of Harvard University Press.

PEN America. (2019, October 11). Book burning at Georgia College is disturbing. Targeted News Service. https://pen.org/pressrelease/gacampusbook-burning/

Peralta, E. (2013, September 11). Pastor Terry Jones arrested before planned Quran burning. NPR. https://www.npr.org/sections/thetwoway /2013/09/11/221528510/pastorterryjonesarrested-before-plannedquranburning

Sclafane, S. (2011). Social-media risks: Facebook dating, book burning \& employee bathing. National Underwriter, 115(11), 20.

The U.S. National Archives and Records Administration. (n.d). The Bill of Rights: A transcription. https://www.archives.gov/foundingdocs/b ill-of-rights-transcript

Vitello, P. (2011, April 23). New Jersey transit worker, fired after burning Koran, wins 
back his job. The New York Times.

https://www.nytimes.com/2011/04/23/

nyregion/nj-transit-worker-

firedforburning-koran-gets-back-

job.html

Webster, F. (2014). Theories of the information society ( $\left.4^{\text {th }} \mathrm{ed}\right)$. Routledge.

Yorio, K. (2019). Libraries see anti-LGBTQIA+ trend: "State of America's libraries 2019" reveals "extreme tactics" by organized groups. School Library Journal, 65(4), 10. 